\title{
Savoring Decay: Cheese, Heritage, and the Allure of Imminent Dissolution
}

\begin{abstract}
This article approaches the theme of "saving food" by taking a fresh look at the renaissance of artisan cheesemaking in recent years. Based upon fieldwork conducted over a decade in thirteen countries, the author suggests that the "death" of cheesemaking traditions and their "rebirth" are simultaneous
\end{abstract}

OVER THE COURSE OF MORE than a decade of research with artisan cheesemakers and cheesemongers, I have frequently heard two apparently opposing narratives-one of the decline and disappearance of cheesemaking traditions, and the other of their renaissance. What if these stories are not contradictory, however? Might they be understood instead as two essential elements of the same historical moment? In what follows, I explore the idea that the contemporary artisan cheese renaissance is inextricably bound up with the historical disappearance of cheesemaking traditions - that these two trends are symbiotic, and that they animate one another. In the world of artisan cheese today, I suggest, decay is savored, and dying traditions are all the rage.

\section{Death and Rebirth in the World of Artisan Cheese}

In August 2005, journalist John Lichfield published an article in the British daily broadsheet The Independent, forecasting "the death of a tradition" in the French Savoie. Seventythree-year-old Célina Gagneux, "the last maker of Vacherin d'Abondance" (a soft creamy cheese traditionally made in the region from cows' milk when herds were kept in the barn during the winter months), was on the verge of retiring. "When I was a girl, there were 30 people or more who made Vacherin in this valley," Gagneux remembered. "Now they've all died or stopped." She told Lichfield, "I am getting old now, and milking cows in the winter, morning and evening, getting up early, bringing in the wood, starting the fire, making the cheese, I don't know if I will have the energy this year. I don't know if we will keep the cows any longer. It's a pity, but there it processes that depend upon one another in complex ways. Invoking the idea that "managed decay" of milk imparts flavor to cheese itself, the author argues that, on a larger scale, the preservation of cheesemaking heritage involves the savoring of dying traditions.

is." Lichfield gave other examples of family-produced, locally distinctive cheeses-which he described as "national treasures" - dying out. Only the year before, he reported, the last maker of Galette des Monts d'Or - which had been made in the hills outside of Lyons "for 400 years" - had died, and "the cheese died with him." He told readers that an estimated 50 varieties of French cheese had "become extinct" since the mid-1970s (Lichfield 2005).

As I have conducted ethnographic research on artisan cheesemaking for more than a decade-work that has taken me to more than 30 different regions in 13 countries, where I have worked with over 200 cheesemakers, as well as affineurs, cheesemongers, and officials with an interest in cheesemaking ${ }^{1}$ - I have heard many such stories of the disappearance of cheesemaking traditions. Just as often, however, I have heard stories about the revival of tradition. For example, I spent time with Joe Schneider in his dairy on the Collingthwaite Farm on the edge of the village of Cuckney in the English county of Nottinghamshire in the autumn of 2006. Together with affineur and cheesemonger Randolph Hodgson, Joe was seeking to recreate a tradition. Some 17 years earlier, the members of the Stilton Cheese Makers' Association had decided to require makers of this famous full-cream blue-veined cow's milk cheese to use pasteurized milk in its production. Randolph had continued to sell Stilton cheese in his Neal's Yard Dairy shops, but was nostalgic for the taste of a cheese that had, as far as he was concerned, ceased to exist in all but name. Together, Randolph and Joe sought to give new life to raw milk Stilton in a cheese they called Stichelton (after the original name for the village that eventually came to be called Stilton) (Hodgson 2007). 
Surprisingly, I have more often heard narratives of declinesuch as Lichfield's account of Vacherin d'Abondance-in countries that most people would associate with stronger and more enduring food traditions, such as France, Italy, Portugal, Greece, and Turkey. Just as unexpectedly, I have more frequently heard narratives of renaissance in countries often characterized as relatively lacking in food traditions, such as the United Kingdom, the Netherlands, and the United States. Upon reflection, this makes sense, as those with whom I have worked often compared the present with the memorable past in the places that they knew best, and extrapolated trajectories in their narratives. In many of the places where I have heard stories of rebirth - of a cheese, or more broadly, of a market for artisan cheese-such narratives have been explicitly offered as sequels, or counternarratives, to tales of disappearance. The tone of such story lines has been echoed by a range of food commentators. In 2009, the organizer of the Great British Cheese Awards, Juliet Harbutt, boasted that there were now some 700 varieties of British cheese -100 more than in France, and nearly twice as many as in Italy! (Marsh 2009). In a 2016 article in the Guardian, food writer Felicity Cloake informed readers that "we are indisputably living in a golden age for British cheese. But this comes after many lean years-even decades" (Cloake 2016). Indeed, while the establishment of the Milk Marketing Board in the United Kingdom in 1933 had ensured that even the smallest, most remote dairy farmers had a guaranteed buyer for their milk, this had prompted many small farmers to abandon long-standing traditions of transforming their milk into more durable foodstuffs such as butter and the "territorial cheeses," like Cheshire and Lancashire, that they had long made. While the Milk Marketing Board had also sold cheeses made by small-scale producers, it had done so at fixed prices that failed to reward small producers for their intensive labor, making it difficult for them to compete with industrial makers who could produce "similar" cheeses for less (Schneider 2006: 14-16). Then, during the Second World War, the British Ministry of Food had requisitioned milk and had mass-produced Cheddar cheese to ensure a stable food source for soldiers and citizens alike, and after the war only a very small number of farmhouse producers had returned to making cheese (Hodgson 2007: 17-19, Dawson 2010: 12-14). This was the baseline against which people with whom I have worked in the United Kingdom measured the state of farmhouse cheesemaking in the present day. Much of what they saw had been reborn.

In the foreword to Jeffrey P. Roberts's 2007 volume, The Atlas of American Artisan Cheese, Slow Food founder Carlo Petrini refers in a similar vein to the "growing number of
American raw milk cheeses" as a "'renaissance' of cultural, productive and food diversity” (Petrini 2007: ix). As in the UK, this renaissance follows on decades - in fact, more than a century and a half-of decline. The industrialization of cheesemaking in the United States began much earlier than in the United Kingdom, with the first true cheese factorywhich purchased milk from multiple farmers and transformed it into cheese-being set up by Jesse Williams in upstate New York in 1851. By the start of the American Civil War, there were 38 such factories in New York state, and with men away fighting in the war, farm families welcomed escape from the drudgery of cheesemaking and, instead, focused their limited labor power on the production of liquid milk. By war's end, some 500 cheese factories were operating in New York state alone, and by the end of the century, farmhouse production was virtually nonexistent (Kindstedt 2005: 29-30). Farmhouse cheesemaking, as witnessed in the United States today, has risen phoenix-like from the ashes of this near-total destruction.

By contrast, elsewhere, the concentration of dairy farming and the industrialization of cheesemaking were far less pronounced before, and during, the Second World War than in the United States and the United Kingdom. Such phenomena have generally still occurred, however, albeit later and perhaps to date less exhaustively. What is more, because they have been experienced more recently with greater intensity, they have in many instances defined cheesemaking into the years in which I have conducted fieldwork. The landscape of French cheesemaking, for example, has been profoundly rewritten in recent decades. Following the Second World War, France rapidly industrialized, and state institutions expanded to govern a rebuilding nation. In the Pyrenees, where dairying and cheesemaking have provided livelihoods to a great many people for centuries, I was told that young men and women left the region in droves in the 1950s and 1960s to take up work as government functionaries (Lassalle 2009: 138). In the Auvergne-another dairying region-young men and women found work manufacturing tires in Claremont-Ferrand, and in other industries, or other cities further afield, in the same period.

Even as urban industries attracted migrants from the countryside, agriculture and food processing were also industrialized, especially in the latter decades of the twentieth century, to better compete in emerging global markets. Artisan producers have themselves struggled to compete with industrial farmers and cheese manufacturers. In cheesemaking regions such as the Auvergne, young men and women have largely abandoned dairying and cheesemaking. When elders have retired, neighbors have often bought their land and scaled up production. Numbers of cheesemakers have therefore declined precipitously, while units 
of production, on average, have grown dramatically in size (West 2014: 75-78). In the meantime, the vast majority of fromageries nationwide closed in the later part of the twentieth century (Véronique Richez-Lerouge of the Association Fromages de Terroir reports that numbers fell from 20,000 to 3,300 between 1979 and 2010, with supermarkets becoming the principal purveyors of cheese in France. Most of the cheese consumed in France today is industrially produced; by 2010 less than $7 \%$ of cheese consumed in France was made from raw milk [Barchfield 2010; Allen 2010]). With supermarkets favoring producers who are able to meet large orders and provide pre-sliced, individually wrapped pieces (Blay 2006: 27), small-scale cheesemakers have largely disappeared, despite the continuing association of France with a multitude of culturally embedded regional cheeses.

Similarly, in Greece, as the raising of livestock became less profitable after the Second World War, and especially in the 1960s and 1970s, ethnic minorities such as the Vlachs and the Sarakatsani-who had long practiced transhumant pastoralismbegan to abandon sheep breeding and cheesemaking and to settle in towns and cities in large numbers, ceding the market for cheese to large cooperatives and industrial producers who now dominate the cheesemaking landscape. Consequently, the popular association of Greek food stuffs, including cheese, with small-scale producers embedded in local and regional foodways has similarly come into question (Oikonomou 2011: 13-16).

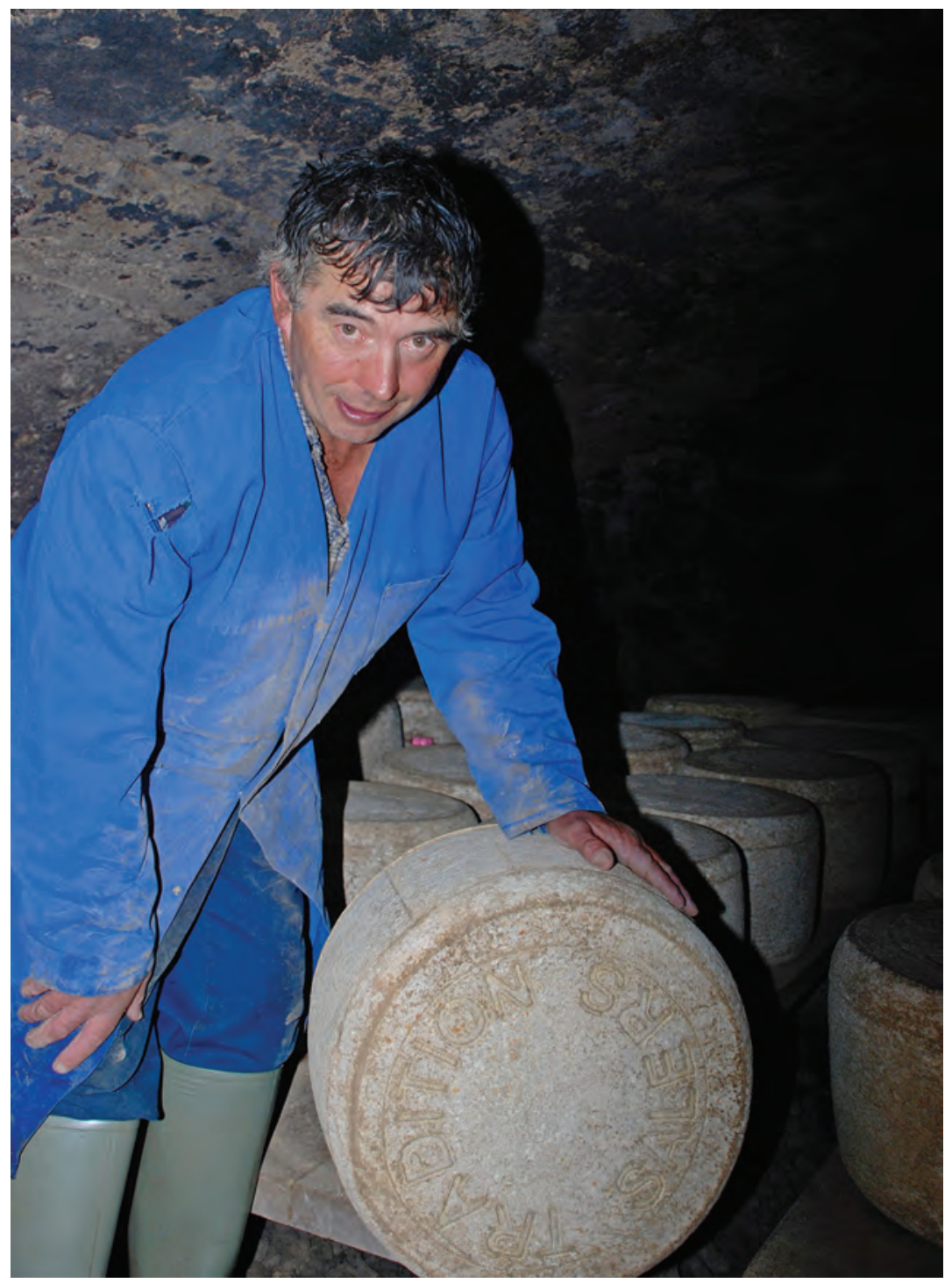

Figure 1: In the aging cellar at Georges Fabre's Tradition Salers buron in high mountain summer pastures, outside Anglards-de-Salers, Cantal, France.

PHOTOGRAPH BY HARRY G. WEST (C) 2019 
In Turkey, too, rural residents have been pulled into fastgrowing cities, while farmers have been pushed out of farming and foodmaking by the appearance in the marketplace of cheap industrial products, and by their inability to afford or adopt the technologies used by the larger-scale manufacturers with whom they must now compete. As elsewhere, herds and flocks have been concentrated in the hands of a smaller and smaller number of larger and larger-scale farmers, and cheesemaking has been consolidated into units of production of increasing size that each purchase milk from hundreds of livestock breeders. In some areas, these processes are less advanced than in others. Some families still maintain small herds, but many of these sell their milk to industrial producers, who send fleets of milk tankers out into the countryside surrounding their plants. While some people continue to make cheese for themselves, stricter food safety laws make it difficult for small-scale cheesemakers to sell their wares in local markets, and the story of a profound link, through food, between the nation and its farmers has increasingly given way to one of disconnection and demise (Çirozlar 2011: 105; Hamarat and Hamarat 2011: 10-13; Kap 2011; Gida 2011: 9; Kardeş 2011: 16, 31).

\section{A Tale of Two Cheeses, or, Two Tales of Cheese?}

Opposing narratives of the death and rebirth of artisan cheesemaking today are more than simply tales of two (kinds of) cheeses or two (kinds of) cheesemaking places. Viewed together, they bear testament to what, for artisan cheesemakers more generally, have been, to paraphrase Dickens, the best of times and the worst of times, the spring of hope and the winter of despair, in which we have everything before us and nothing before us (Dickens [1859] 2003). It is not merely the case that some cheeses are dying while others are reborn, nor that some places are sites of the disappearance of cheesemaking traditions and others the sites of their renaissance. Indeed, narratives of death and rebirth in the world of artisan cheese today derive force not only by comparison with the recent past in each particular place but also by juxtaposition with one another-by what Dickens calls, in the opening paragraph of A Tale of Two Cities, a "superlative degree of comparison" (ibid.). A 2011 film airing on French television, entitled The War of the Stinky Cheeses, informed viewers that, while the production of artisan cheese was exploding in the United States and Canada, artisan cheesemaking was imploding in France. The ancestral savoir-faire that underpinned varieties of cheese associated with every province and every terroir, and that was recognized by gastronomes around the world, was in jeopardy, the film told viewers, as machines were replacing people in the production of France's cheeses, as appellations with long histories were disappearing, and as supermarkets were supplying the majority of the French with industrial cheeses. By contrast, the film reported, the volume of farmstead cheese being made in the United States and Canada had grown by 1,000\% in the last 20 years, and consumers in this vast market were increasingly sourcing their cheese-much of it cheese of fine quality - from North America rather than France. ${ }^{2}$ The juxtaposition of the death of cheesemaking in le pays de la gastronomie and its renaissance in le pays du malbouffe had a powerful effect on French audiences. ${ }^{3}$

To be sure, the presentation of contrasting states-of-affair has often enhanced the power of narrative in the world of artisan cheese. But narratives of death and rebirth are even more entangled than this. In many of the places where I have worked, narratives of decline and renaissance have held sway simultaneously, often being articulated by the same people. The anthropologist David Berliner (2015: 20) writes: "At first glance, nostalgia constitutes a consuming and painful feeling born of the realization that human temporality is irreversible, that return is impossible." But among cheesemakers with whom I have worked, this was not necessarily so. In the Netherlands, for example, I have often been told that the number of farmhouse cheesemakers is in decline (van de Voort 2009: 71). Trees van Leeuwen-who makes a cheese named after the town of Leiden - told me that, where once there were 75 makers of Leiden, there were now 13 (only 6 of whom made the cheese by hand). However, on the same day, she then told me optimistically that a farmer in the region who currently made only Gouda would soon start making Leiden as well (van Leeuwen 2009: 46-49). By her account, Leiden cheese was disappearing and reappearing at the same time.

The account given to me by the French cheesemonger Herve Mons similarly comprised two opposing trends. He told me that Anglo-American foodways had only taken root in France in the last 20 years. Paradoxically, in his view, at the very time that America and Britain had begun to see the absurdity of modern industrial foodways and to change course, France had begun heading down this path. "When you come here with the idea that France is the France of our grandmothers, who continue to make cheese as they did, what you will see is enormous factories, crazy things-but where are they, the peasants who made the original cheeses?" At the same time, Mons saw another side to this coin. Whereas his parents' generation traveled the world and discovered other things, Mons said, he saw his generation's challenge as rediscovering the world that his parents had left behind and the culture that they had abandoned (Mons 2008: 6-9). As he described it to me, both of these phenomena were occurring simultaneously. 
Merely to associate narratives of death and rebirth with particular cheeses (the death of Vacherin d'Abondance, the rebirth of Stichelton), or with particular places (decline in France and southern Europe, renaissance in Britain and the Anglophone New World) would gloss deeper complexitiesa world in which narratives of death and rebirth not only coexist, and reveal contrast through juxtaposition, but are also inextricably linked. Rather than a tale of two cheeses, the accounts that I have gathered would seem to constitute two tales of cheese, being told on the same stage, in powerful dialogue one with the other.

\section{A Living Thing, A Dying Thing}

In the space that remains, I wish to explore in more depth the idea that, in the world of artisan cheese, the death and rebirth of cheesemaking traditions are not merely opposites; they depend upon and lend force to one another in profound ways. To lay foundations for this, I wish for a moment to look at artisan cheese on another scale in which demise and revitalization are also inextricably bound - the microbiological scale.

Aficionados often speak of cheese as a "living thing." They warn against wrapping it in plastic because it "needs to breath." They also often advise against storing it in a refrigerator, which might "slow its metabolism." But cheese is as much a "dying thing" as a living one. The milk from which cheese is made is already in decay as it leaves the udder, as indigenous and atmospheric microorganisms feed on it, breaking down its component parts. As Leon Kass (1994: 26) reminds us, "Eating comprises the appropriation, incorporation, and de-formation of a complex other, and its homogenization into simples, in preparation for their transformation into complex same." This is as true of microorganisms feeding on milk as of humans consuming cheese. As Kass writes: "to preserve their life and form living forms necessarily destroy life and form" (12).

Paradoxically, the "life" of cheese lies in the very microorganisms - cultivated by the cheesemaker - that bring about milk's slow decomposition. The decomposition of the milk/ curd as it "ages" evinces the life of the microorganisms that inhabit it-bacteria, molds, and fungi that are as much a part of milk/cheese as milk proteins and fats (Koçulu 2011). In a well-made cheese, these microorganisms fend off pathogens by outcompeting them. Simply put, fermentation-defined by McGee (2004: 58) as "essentially a process of limited, controlled spoilage ${ }^{6}$-entails forestalling some forms of decomposition by fostering others. ${ }^{7}$ By cultivating microorganisms that feed on the curd-by orchestrating milk's slow decaycheesemakers prolong milk's shelf life, and give birth to the cheese itself.
Building on Kass and McGee, I would argue that cheesemaking is thus a process of managed decay, akin to that described by the geographer Caitlin Desilvey (2017: 11) when she writes: "Decay occurs when a complex of biological, chemical, and physical processes-each driven by specific agents and elements - combines to break down the integrity of a substance and to make its components available for enrollment in other projects ... As Jane M. Jacobs and Stephen Cairns point out, 'Biological and ecological concepts of decay are full of activity, exchange, acquisition and redistribution. Decay is as life-giving as it is life-taking."

The intertwined processes of life and death that constitute decay may meet with ambivalence on the part of those who perceive and experience them. The psychologist Paul Rozin (1999: 25) has suggested that "the quintessential odour that elicits disgust is the odour of decay, that is, of death." But cheese elicits more complex responses than this. To be sure, some cheeses may offend people's senses. Washed-rind cheeses such as Muenster, Taleggio, and Epoisse are often described-and not always fondly - as "stinky" cheeses, an adjective that Stinking Bishop embraces with playful pluck. Indeed, some people find all cheese disgusting. Historically, fermented milk curd has had quite limited appeal in East Asia; exceptions may be seen as departures from a norm to which they inevitably call attention (Klein 2018). In Western societies, cheese may evoke widely disparate responses. In Claude Lévi-Strauss's famous article “The Culinary Triangle," he tells us that, following the Allied landing in 1944, American troops advancing through the Norman countryside sometimes burned down dairies because they mistook the smell of cheese for corpses (Lévi-Strauss 1966: 587). Whether or not this actually happened-such accounts may tell us as much, or more, about French perceptions of lacticly uncultured Americans than about American perceptions of French cheeses - the story graphically illustrates the idea that human responses to decay are highly variable, even fungible. Such responses are in line with the volatility of human reactions to decay more generally addressed by Desilvey (2017: 24) when she describes her own visceral response to sifting through material artifacts in a contemporary archeological site: "I am not particularly squeamish, but the edge of revulsion was never far away. I worked close against the margin where the 'procreative power of decay' [here, she cites Bataille (1993: 81)] sparks simultaneous - and contradictory-sensations of repugnance and attraction."

Cheese provokes such contradictory sensations not only because it concentrates milk and intensifies its taste, but also because fermentation releases flavors that would not otherwise express themselves. Harold McGee (2004: 58) explains that, through fermentation, "animal fats and proteins are broken 


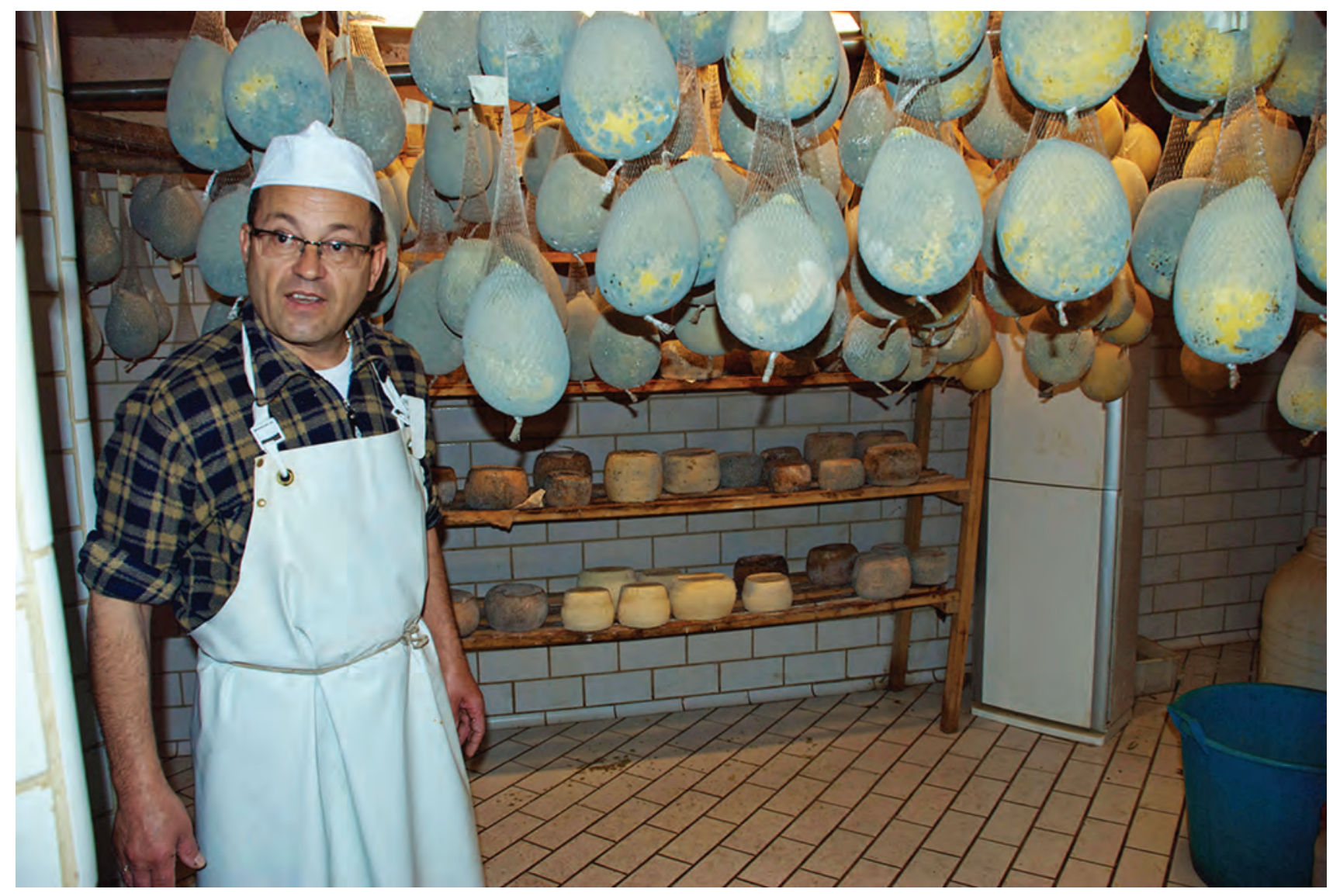

Figure 2: In the curing room at Rosa Bottone's Latteria Santa Caterina, Scala, Campania, Italy.

PHOTOGRAPH BY HARRY G. WEST (C) 2019

down into highly odorous molecules. Many of the same molecules are also produced during uncontrolled spoilage, as well as by activity in the digestive tract and on moist, warm, sheltered areas of human skin." As a result, McGee tells us, cheese is "an intense, concentrated expression of pastures and animals, of microbes and time" (51-52). McGee goes on to say that "[a]n aversion to the odor of decay has the obvious biological value of steering us away from possible food poisoning, so it's no wonder that an animal food that gives off whiffs of shoes and soil and the stable takes some getting used to" (58). But "get used to it" many do. McGee explains: "We allow certain microbes and their enzymes to decompose the original food, but not beyond the point of edibility." What is more, he tells us, this "controlled spoilage" may give rise to substances that elicit delight. "Once acquired," he writes, "the taste for partial spoilage can become a passion, an embrace of the earthy side of life that expresses itself best in paradoxes ... The surrealist poet Leon-Paul Fargue is said to have honored Camembert cheese with the title les pieds de Dieu - the feet of God" (58).

One might, of course, conceive of all fermented foods - such as pickles, charcuterie, sourdough bread, beer, wine, cider-as the products of "controlled spoilage." But the language used to describe cheese often refers to this more explicitly. Mother Noella Marcelino, who makes cheese in the Benedictine Abbey of Regina Laudis in Bethlehem, Connecticut, reflected on this when I conversed with her in the summer of 2003 . She remembered to me what Jim Stillwagon-a cheesemaking friend of hers-had once pointed out to her: whereas the language used to describe wines, with its floral "bouquets," so often pointed upward, to the heavens, the language used to describe cheeses generally pointed down, to the ground: sweaty socks and feet, wet dogs and manure. In cheese, however, this groundthis place of dirt, death, and decay - is celebrated. In cheese, the rotten becomes tasty. In other words, those who sustain predilections for cheese explicitly savor decay (West 2014: 86).

\section{Clasping the Dying}

Let us now move back from the scale of microbial cultures to that of human cultures. Whereas Kass has told us, above, that life and death are mutually constitutive along the food chain, the anthropologists Maurice Bloch and Johnny Parry observed 
many years ago that the same is true in the realm of social relationships. ${ }^{8}$ With reference specifically to mortuary rites, they wrote: "death is a source of life. Every death makes available a new potentiality for life, and one creature's loss is another's gain." Further, they suggested, the corollary is "that the regeneration of life is a cause of death" (Bloch and Parry 1982).

Following this lead, cheesemaking might best be understood, like cheese itself, as a complex of cultural practices in which, echoing Desilvey, breakdown constantly renders components available for enrollment in new projects - in which, borrowing from Kass, death (the destruction of life and form) is intimately bound up with life (the preservation of life and form). Not only do tropes of death and rebirth work across these scales, echoing one another, they may also be seen as elements of a fractal whole, for their use, and the phenomena they describe, on the micro scale are the very stuff of their use, and the phenomena they describe, on the macro scale.

The St. Nectaire cheesemaker Alphonse Bellonte-with whom I worked closely over the course of several summers in the French Auvergne between 2006 and 2009-often spoke of his and his family's work as cheesemakers as a "living tradition," emphasizing that it was a tradition that had to be continually remade in order to remain viable in the modern world and, thus, to remain alive (West 2014: 86). Such constant rebirth, he told me, was inevitably linked to constant deaths of one kind or another. For example, to preserve the health and well-being of family members who spent long days in the damp cheese room pressing the curd by hand (and who consequently came to suffer the effects of carpel tunnel syndrome), Alphonse's family acquired a hydraulic press. This marked the end of a time-honored tradition of hand-pressing, but at the same time gave new life to their family cheesemaking practice (West 2014: 86-87). In the Portuguese Alentejo, Nuno Domingos and I worked with Serpa cheesemakers who abandoned the traditional practice of aging their cheeses in the rafters of their cheese rooms, opting instead to age them in refrigerators. This was a transformation that attracted critique from Slow Food (who saw it as a technological corruption of tradition), but one that allowed Serpa producers to significantly reduce waste and to survive in the face of competition from larger, more industrialized producers (West and Domingos 2012: 130-32). In her work on American artisan cheesemakers, Heather Paxson suggests that innovation is itself considered part and parcel of tradition by many cheesemakers who celebrate what Paxson calls "traditions of invention." She writes, "what is enshrined as a matter of cultural heritage ... is continual change, not continuity" (Paxson 2013: 113).

Paxson moves us beyond the idea that tradition is dynamicthat it is constantly (re)invented, or reborn-to focus on the sentiments such reinvention engenders. Where she follows the lead of the American cheesemakers with whom she worked in focusing on dispositions toward innovation, however, I wish to reflect upon sentiments regarding the ideas of the death and the renaissance of cheesemaking that I have so frequently encountered over the last decade. Just as the decomposition of curd invokes varied, often complex, responses from those who taste cheese, so too has the idea of the decay of cheesemaking traditions.

Narratives such as the one put forth in The War of Stinky Cheeses, referred to above, convey a sense of revulsion and disgust that the hand of man is being replaced by the machine, and that traditions with deep history are disappearing forever. But of course, such accounts foster a sense of urgency-calls for redress born precisely from such revulsion. In the words of historian David Lowenthal (1985: 399), "Nothing so quickens preservation sympathies as the fear of imminent extinction, whether of a building, a bird, or a folkway" - to this, we might add, a cheese.

Lowenthal also observes that, beyond engendering sympathy, decay itself may be "pleasing" (149): "That aging adds beauty, with colors becoming more perfect as time goes on, was the common view of [art] connoisseurs by the seventeenth century. The Italian word 'patena', originally a dark varnish applied to shoes, denoted the flattering tones time induced on varnished paintings" (159). For those celebrating the picturesque ideal in eighteenth- century England, such as John Ruskin, Lowenthal writes: "Erosion lent beauty a temporal dimension, for 'set in the deeper places of the heart [is] such affection for the signs of age that the eye is delighted even by injuries which are the work of time"' (165). Whether for a Smithsonian Institution conservator leaving "handsome patina ... intact," or for recording studios "preserv[ing] scratches in old recordings," or for history students "thrilled to handle nineteenth century diaries and travel logs" whose " "crinkle of antiquity [promises] ... that some major discovery might be lurking in those yellow pages" (149, 153), Lowenthal suggests that decay may not only certify authenticity, but also in and of itself be considered aesthetically appealing (152-63).

According to Lowenthal, it is not just aging that is celebrated here, but decomposition. "Ruskin admired decrepitude," he tells us. "By picturesque tenets, 'a broken stone has necessarily more various forms in it than a whole one; a bent roof has more various curves in it than a straight one; every excrescence or cleft involves some additional complexity of light and shade, and every stain of moss on eaves or walls adds to the delightfulness of color" $\left({ }_{16} 5_{5}\right)$ - just as the breakdown of curd is said to produce greater complexity of flavor and more pleasing aromas and tastes. 
The sociologist Jacinthe Bessière has applied such notions to disappearing foodways. Writing specifically about the use of traditional food and cuisine in tourism and local development in rural France, she has asserted: "objects are grasped just as they are about to disappear and their beauty is measured through the shock generated by emotion and memory ... [what Fabre describes as] 'the beauty of death"' (Bessière 1998: 28; Fabre 2007). Bessière's observations not only remind us of how food, too, may be an object found pleasing in decay, but also suggest that the same sentiments may pertain to immaterial culture, including the artisanship associated with a food's production and the foodways that give context to its consumption.

Accordingly, the beauty of an artisan foodway may be perceived and appreciated precisely when its fragility or impermanence is recognized and the threat of its disappearance becomes real. Desilvey (2017: 5) tells us "encroaching absence may paradoxically facilitate the persistence of memory and significance." Such a view echoes that of Lowenthal (1985: 179), who has written: "Imminent dissolution renders many things more precious, and reminders of life's transience can enhance what remains of it." To this effect, Lowenthal quotes the nineteenth-century English poet William Johnson Cory:

All beauteous things for which we live

By laws of time and space decay.

But oh, the very reason why

I clasp them, is because they die

Mimnermus in Church (Cory [1858] 1905: 6)

\section{Preservation and the Requisite Recognition of Loss}

Many of the cheesemakers and cheesemongers that I have met over the years have seen what they do and what they make as significant precisely because of an encroaching absence, to paraphrase Desilvey, or have perceived it as precious because of the potential for its imminent dissolution, to paraphrase Lowenthal. Their frequent focus on the need to persuade others of this was revealing. Even as some told me of their work to revive a dead or dying cheese, they also spoke of the simultaneous need to alert others to the death that their efforts addressed.

David Clarke, for instance, was inspired to make artisan Red Leicester cheese on his farm in Upton, in the English county of Warwickshire, when an older acquaintance shared with him boyhood memories of buying Red Leicester from the last farmhouse maker, and of how good this cheese had tasted. David's wife, Jo, questioned the wisdom of his plan, because Red Leicester-which had long been made only industrially - had a very poor reputation. But David hoped to give new life to the cheese by making it as it once had been, from raw milk, which would afford it more complexity of flavor. He told me that they resolved, "If we could produce it how he remembered it, that would be a good target." Remembering the cheese actually became an interactive project between the Clarkes and their customers. David told me: "We do three farmers markets, and for some time, people would be walking past, and they would say, 'I don't like Red Leicester,' and they'd walk past. And the only thing you could do to get them to try it was to say, 'Look, I made it myself, on the farm-we make it, just down the road.' And they'd say, 'Well, go on then.' And they'd taste it and stop, and they'd say, 'Oh, I remember it being like that.'” Jamie Montgomery, who makes raw milk Cheddar in Cadbury, in the English county of Somerset, similarly told me that his greatest challenge had been getting people to taste a cheese whose reputation had long been sullied by industrial production. But once he got it in their mouths, he told me, he could see them, sometimes with misty, nostalgic eyes, remembering-as well as realizing that they had forgotten in the first place-what it once tasted like. "That's when I knew I had them!" he told me. Both Clarke and Montgomery subtly point out how memory sometimes requires first realizing that one has forgotten. In the interactions with customers that they describe, the taste of their cheese subconsciously conjures for the taster the specter of its very death even as it comes back to life on the palate. ${ }^{9}$

For many others with whom I worked, the need to reestablish a link between living tasters and a dead or dying tradition required more explicit framings. Elsewhere, I have told the story of how Alphonse Bellonte-the St. Nectaire cheesemaker referred to above-turned a complex of aging caves on his farm into a museum that set the story of cheesemaking in his hamlet within the context of a rich regional history (West 2014). The museum attracted visitors who watched his family make cheese, who took meals in the on-farm auberge that served their cheese, and who bought cheeses in the farm shop to take home with them. In more than a dozen other places, I have seen museums that tell the story of a cheesemaking tradition. Some of these have been set up by individual makers like Bellonte, some by cheesemaker associations, cooperatives, or syndicates, and some by public institutions such as village or regional councils or tourist boards (West 2016). In varied ways, these museums not only inject life into the cheesemaking traditions to which they refer, they also cast such traditions as forms of heritage, suspended between a past in which they are rooted, and a future that threatens their very existence. The faded black and white images of past makers, the dated fonts of old labels, the worn or broken wooden tools, the antiquated language of the quoted words of forebears, all remind the 
visitor that this living tradition is aging, like all things, moving toward its end, even as it invites visitors to forestall its deathto prolong its life-by recognizing its distinctive forms of value and by consuming it. ${ }^{10}$

On a broader plane, regional and national governments in many of the places where I have worked have embarked upon the creation of "inventories" of food heritage. Such projects are generally cast not only as means of recognizing traditional foods and foodways, but also as vehicles for the preservation of such traditions in the face of forces that threaten their survival. In some cases, such inventories feed into the project of establishing appellations or indications of origin that legally restrict the use of place names in the marketing of such foods to those who work within a specified area and follow an agreed-upon set of productive guidelines, all grounded within a certified historical tradition (West 2013). In other cases, such inventories have given foundation to applications to the United Nations Educational, Scientific and Cultural Organization to have foods and foodways officially recognized as elements on UNESCO's Representative
List of Intangible Cultural Heritage of Humanity. Tellingly, this UNESCO list arises from its 2003 Convention on Safeguarding the Intangible Cultural Heritage-a project framed in part by the simultaneous recognition of "grave threats of deterioration, disappearance and destruction of the intangible cultural heritage" (UNESCO 2003).

Museums and inventories are just two examples of means through which artisan cheesemaking today is cast as a form of cultural heritage. Others include farm shops and agritourism, workshops held by cheesemakers or cheesemongers, festivals dedicated to a particular cheese or cheesemaking tradition, and the establishment of tourist routes/trails (directing visitors to specific producers) or farm-to-restaurant networks. I have written about these in greater detail elsewhere (West 2016). What bears pointing out here is that such strategies all partake in one way or another of a broader project of heritagization-one that Gade (2004: 848) has described as "a salvage effort akin to preserving a language or a plant species from extinction." ${ }^{11}$ In so doing, they give life precisely by invoking the possibility of death.

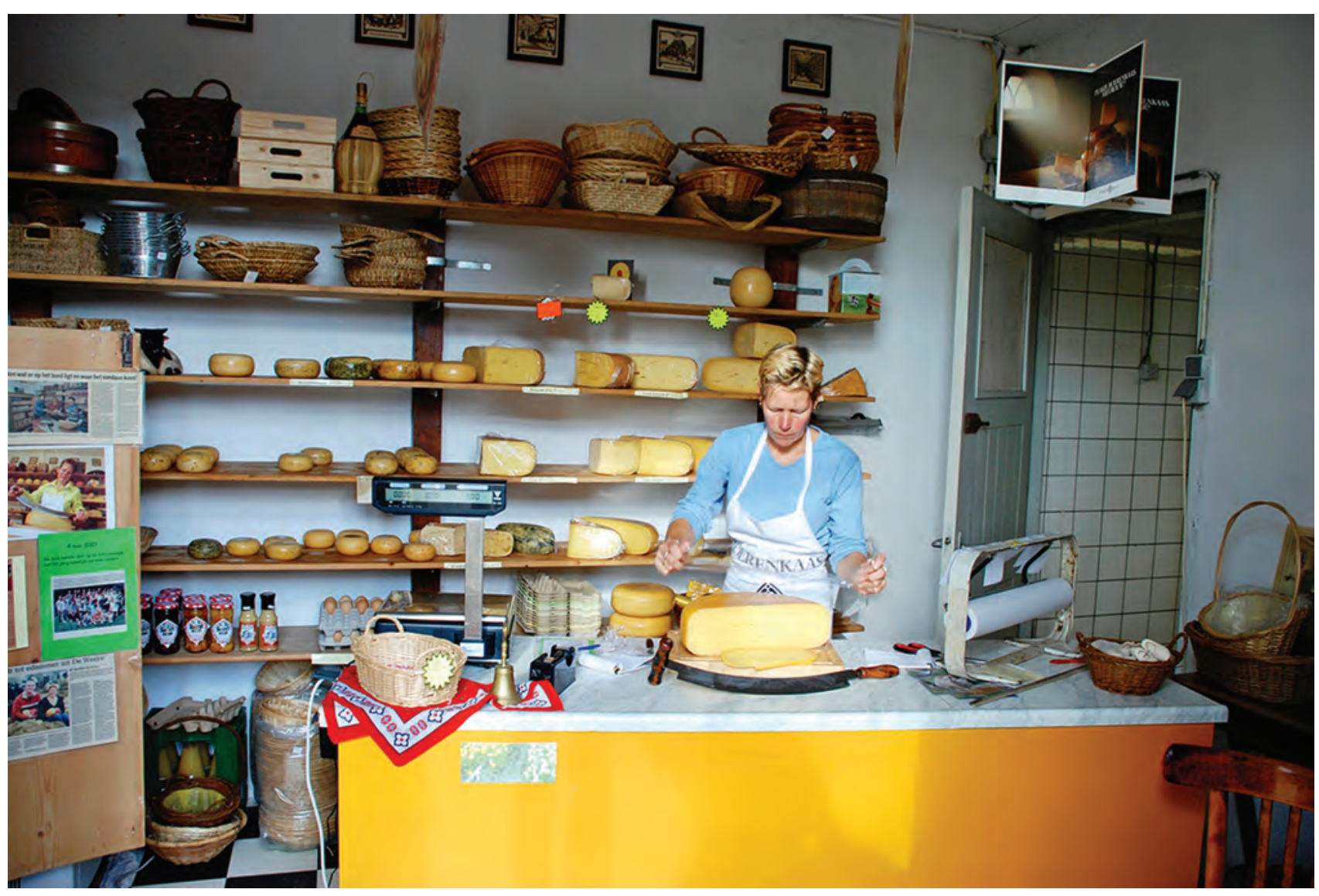

Figure 3: In the farm shop at Siaak and Lia Koopman's dairy in De Weere, Opmeer, North Holland, the Netherlands.

PHOTOGRAPH BY HARRY G. WEST ( 2019 


\section{Dying Traditions Are All the Rage}

Thus far, I have cited Desilvey in support of my argument that the idea of renaissance in the world of artisan cheese today is inseparable from desires to preserve cheeses and cheesemaking traditions from decay and impending death. It is worth noting that Desilvey's primary objective is somewhat different; at a time when we sometimes seem to be trapped and overwhelmed by the impulse to preserve everything, she aims to persuade readers to let go of the project of preservation in cases where it may not be possible or desirable and, instead of fighting against decay, to come to terms with-even appreciate-its occurrence. This may make sense with reference, for example, to harbor walls in a seaside town battered by waves as oceans warm, water levels rise, and storms grow in intensity. But most of the cheesemakers I have worked with have persisted in their desires to preserve artisan traditions, or to give them rebirth, for reasons that I suspect Desilvey would appreciate, for she has herself suggested that "the active cultivation of material dissolution and disappearance" that she espouses (Desilvey 2017: 43) may not be appropriate where the preservation of heritage gives foundation to livelihoods and social identities (59-60). For a great many with whom I worked-whether cheesemakers or cheesemongerscheese was indeed a livelihood and an identity. But even Desilvey's central argument is useful in understanding these livelihoods and identities, for as I have argued above, artisan cheesemakers and cheesemongers today not only work to preserve cheesemaking traditions, they often do so in part by calling attention to-even curating - their decay.

Desilvey (2017: 5) tells us, "processes of decay and disintegration can be culturally (as well as ecologically) productive." Managed decay may also be economically productive. Olivia Angé (2015: 195) suggests in her study of barter fairs in the Andes that "while the nostalgic disposition supposes longing for a future shaped through the prism of a vanishing past, strategic nostalgia's intentional scope focuses on present affairs." Indeed, most artisan cheesemakers with whom I have worked have been every bit as focused on "present affairs" as on the past. While a few have made cheese as a hobby, or have subsidized their cheesemaking with wealth from previous careers or business pursuits, most have made cheese to earn a living, and have had to pay close attention to the bottom line. And many who have succeeded in making a living from making cheese have done so by translating the normative values many attach to artisan cheesemaking into monetary value (Paxson 2013: 78-79). So too did most of the cheesemongers with whom I have worked. Indeed, there is a global network of specialty cheesemongers linking places like Saint Haon le Châtel (France), London, Galway (Ireland), Amsterdam, New York,
Melbourne, New Delhi, Dubai, Shanghai, and Tokyo-to name but a few nodes - that, like the fairs Angé describes, nurtures nostalgia and creates robust market demand for dying cheesemaking traditions.

The burgeoning global market in "artisan" and "heritage" foods has been broadly attributed to consumer wariness of industrial agriculture and processed foods, lately exacerbated by dramatic food scares and the threat of bioterrorism, the perceived disconnection of an increasingly urban global population from a "disappearing countryside" and associated forms of agrarian or craft heritage, and a global environmental crisis giving rise to increasing public concerns about the unsustainability of food systems and the erosion of biodiversity. These threats variously raise the specter of decay and death-whether of consumer confidence, of artisan skill, of community, or of ecosystems. And in response to each, artisan foods promise not so much to reverse time as to locate, preserve, or derive something more pleasing from within a broader environment of decay. ${ }^{12}$

The scale and intensity of this market niche represents a profound paradox, captured poignantly in my conversations with colleagues in Athens. Leonidas Louloudis, Professor at the Agricultural University of Athens, told me that there was rising interest in Greece in local, artisan cheeses. His colleague Andromachi Oikonomou-a Senior Researcher at the Hellenic Folklore Research Centre in the Academy of Athens-told me that this rising interest was fueled by perceptions that traditional Greek foods were disappearing (Oikonomou 2011: 25-28). What these colleagues described was the inverse of the paradox attributed to the American baseball player Yogi Berra, who is credited with observing about a popular New York night club, "No one goes there anymore, it's too crowded." In the case of artisan cheese, it might be said, "Everyone is making it now, since no one is making it any more."

Indeed, "dying traditions" have in many places become "all the rage." Consider the story of Alex James. After achieving fame as the bassist for the British rock band Blur, James bought a farm in the Cotswolds and started to make cheese. He began writing a regular column in The Independent celebrating his bucolic experience, and subsequently developed a line of cheeses for Asda, the British arm of the American retailer Walmart. But just as rock stars like James have become cheesemakers, cheesemakers have in recent years become the rock stars of the food world. The American Cheese Society organizes "Meet the Cheese Maker" sessions at its annual conference each year, where journalists, food writers, retailers, and even other cheesemakers can meet these "celebrities" in person. At the 25th Annual Conference of the American Cheese Society in Chicago in 2008, society president and cheesemaker 
Allison Hooper said: "We're not really doing anything different today than we did twenty years ago, but just the perception, or the value of what we do, is so changed" (Hyatt et al. 2008: 38). This was confirmed by Steven Jenkins, a cheesemonger and author of The Cheese Primer (1996), who said: "In twenty, thirty years, there's gonna be a pantheon of American cheese making superstars that really have changed everything from 2000-2008 ... that's where we really began with our great heritage of cheese making" (Hyatt et al. 2008: 39).

The leading British cheesemonger, Neal's Yard Dairy, regularly brings individual cheesemakers to London so that their customers can meet them. When I visited Quinlan Steele in his dairy in Eyeries on the Beara Peninsula in County Cork (Ireland), he told me: "If I'm working away here for months on end and I'm not socializing with cheese fans, as it were, and I lose my motivation ... and I go off to Neal's Yard, I'm just like, yeah! ... Sometimes I think to myself, this is like performing on stage ... We get to be recognized and respected for what we do. It's lovely" (Steele, Steele, and Steele 2009: 70).

It is not only in the food world that cheesemakers are garnering admiration. During one of my stays with Stichelton cheesemaker Joe Schneider and his family, the new copy of GQ magazine arrived-not because Joe subscribed, but because the story of Joe and his cheese was told inside! What readers found alluring was not simply that Joe made cheese. It was rather that Joe was giving rebirth to a dead cheese, to a dead tradition, and to a forgotten past. Joe put it like this in conversation with me: "Here's this cheese that's considered the king of English cheeses - really, in its current manifestation, a mere shadow of its former self-we don't even know what that former self was now. There are a handful of people that have an accurate memory of what unpasteurized Stilton tasted like in the 80's, and nobody's had it since. And nobody's had farmhouse Stilton since the 30's ... So from that point it was just ticking all my boxes as a cheesemaker. So, good fun, fantastic, bring back raw milk Stilton, a complicated cheese, a lot of history, a lot of tradition. Doesn't seem like the industry wants to do it, so we could do it. We could make it high profile, it would be exciting" (Schneider 2006: 23-25).

Not only has the disappearance of a cheese or the death of a cheesemaking tradition given rise to enthusiasm for revival, as Joe expressed, but the value afforded to such acts of revival has in fact fueled narratives that feature dead or dying cheeses and the cheesemaking traditions associated with them, as well as the attendant quest for their (re)discovery. Chris Dawson, the cheese buyer for the upmarket British supermarket chain Waitrose, shared Joe's excitement about playing a role in giving rebirth to dead or dying cheesemaking traditions. He told me, "What's lovely is to see cheeses that have died out-we call them 'forgotten cheeses'-be revived." He celebrated the revival of the French cheese Epoisse (which he described as a "national treasure"), as well as Red Leicester in the United Kingdom (which he called "a classic"), and told me that Waitrose was actively looking to play a role in bringing back forgotten cheeses or recipes that had died out, such as raw-milk Wensleydale (Dawson 2010: 35-38).

The project of giving rebirth to dying traditions has even enlisted consumers. "Save a cheese" was the slogan of Slow Food's Ark of Taste project, put out in advance of its 2013 Cheese festival in Bra (Italy). The organization told members and attendees, "we are inviting you to nominate a dairy product you want to save. Whether you are coming to the event or not, we invite you to hunt down these endangered cheeses: investigate the products in your area, remember a cheese you ate with their $[$ sic $]$ family twenty or thirty years ago or think about someone you know who still raises animals and has a creamery. Then nominate it for the Ark of Taste" (Slow Food 2013).

Desilvey (2017: 13) tells us that "[t]he act of 'saving' implicates us, as individuals, in the biography of an artifact." She quotes Cornelius Holtorf and Oscar Ortman, who suggest: "We prefer ... a past that is fragile, cannot be replaced, and needs our help ... One might even say that archaeological sites are not being saved because they are valued, but rather they are valued because they are being saved" (178). Whether for cheesemakers, cheesemongers, or consumers, the same might well be said of artisan cheeses today. People clasp them because they die-they savor their decay-and in so doing, they give them new lease on life. @

\section{Acknowledgments}

Comments on drafts were generously provided by Emma-Jayne Abbotts, Paul Cleave, Jessica Fagin, Nora Katharina Faltmann, Lizzie Hull, William Jaggard, Iza Kavedzija, Jakob Klein, Anne Murcott, Celia Plender, James Staples, Amy Trubek, Becca Wheeler, Tim Wilkinson, Sami Zubaida, and two anonymous reviewers for Gastronomica.

NOTES

1. Fieldwork was funded by the British Academy (LRG 45537).

2. This was confirmed by retailers across the spectrum at a panel held at the 25th Annual Conference of the American Cheese Society in Chicago in 2008 which I attended: Bill Hanson of Costco Wholesale stated that $45 \%$ of their fine cheese offer was American made; Cathy Strange reported that $60 \%$ of the cheese sold at Whole Food Market was of American origin; and Steve Jones of Steve's Cheese in Portland, Oregon, said that $40-45 \%$ of his fine cheeses were American (Werlin et al. 2008: 84). 
3. See also the 19 November 2006 episode of the BBC Radio Four Food Programme, documenting an event organized by the British Embassy in Paris summed up by presenter Sheila Dillon as follows: "Eight British cheese makers, along with Randolph Hodgson (owner of Neal's Yard Dairy in London) ... have been asked to tell the aristocracy of the French cheese industry what's happening here [in the UK] and to give them a taste of the best, because over the last twenty years, our farmhouse cheese making has gone from strength to strength, while the number of top fromagers in France has declined steadily."

4. Harold McGee (2004: 64) tells us that trapped moisture and insufficient oxygen promotes the growth of nonindigenous bacteria and molds, and prevents the dispersal of ammonia, while plastic can itself interact with cheese to its detriment.

5. McGee (2004: 63) further tells us that refrigeration "puts cheese into suspended animation."

6. Others use different language to describe fermentation. However, I invoke McGee here precisely because of the terms that he uses, which resonate with the language used by many with whom I worked.

7. This is, of course, true not only for cheese but for any fermented food.

8. My thanks to Jakob Klein for calling this to my attention.

9. The experimental psychologist Charles Spence has shown how environmental context and sensory stimuli profoundly affect the experience of taste. Here, Clarke and Montgomery show how taste is affected by the transformation of cognitive context through the stimulation of memory and/or the invocation of nostalgia for the past. The anthropologist Emma-Jayne Abbots - who also worked as a cheesemonger-told me that she and her colleagues often framed their customers' taste experiences with narratives that conjured not only flowers in bloom in the pastures where dairy animals grazed, but also productive traditions rooted in historical time.

10. See also MacDonald 2013

11. The kinds of initiatives that Gade refers to here are akin to "salvage ethnography," whose aim is conceived of by its practitioners as documenting and, wherever possible, preserving "disappearing worlds." My thanks to Anne Murcott for pointing this out.

12. Whereas marketing is often an endeavor to cast a product as desirable because it is new and exciting, here excitement lies in the return of the old-something vintage, or retro, that has newly returned. 13. Of course, the "everyone" now making cheese may be different than the "no one" no longer doing so. In the context of modern consumer societies, wherein the children of farmer/cheesemakers with whom I worked were not defined by the work of their parents and often sought different careers, newcomers to cheesemaking included not only well-educated young urban "hipsters" (see also Ocejo 2017) but also people who had made their fortunes in the financial sector or in the practice of law and had taken up cheesemaking as a lifestyle occupation. By contrast, migrants from the Punjab worked in dairies I visited in Crete, while I spent time with Moroccans making Parmigiano-Reggiano in Emilia Romagna. Such demographic shifts in their own right constituted forms of social reproduction at enterprise level, but also the simultaneous decline and revitalization of cultural traditions such as cheesemaking within the broader context of modernizing cosmopolitan societies.

\section{REFERENCES}

Allen, Peter. 2010. "Fromgirls Fight Back against Drop in French Cheese Sales." Telegraph, 26 February.

Angé, Olivia. 2015. "Social and Economic Performativity of Nostalgic Narratives in Andean Barter Fairs." In Anthropology and Nostalgia, edited by Olivia Angé and David Berliner, 178-97. New York: Berghahn.

Barchfield, Jenny. 2010. "France's Distinctive Cheeses Are Disappearing." Huffington Post, 7 February.

Bataille, George. 1993. "Volume II: The History of Eroticism." In The Accursed Share: An Essay on General Economy, edited by George Bataille. New York: Zone Books.

Berliner, David. 2015. “Are Anthropologists Nostalgist?” In Anthropology and Nostalgia, edited by Olivia Angé and David Berliner, 17-34. New York and Oxford: Berghahn.

Bessière, Jacinthe. 1998. "Local Development and Heritage: Traditional Food and Cuisine as Tourist Attractions in Rural Areas." Sociologia Ruralis 38(1): 21-34.

Blay, Bernard. 2006. Interview. Directeur, Syndicat du St. Nectaire, Besse-en-Chandesse, Puy du Dôme, France, 18 September.

Bloch, Maurice, and Jonathan Parry. 1982. "Introduction: Death and the Regeneration of Life." In Death and the Regeneration of Life, edited by Maurice Bloch and Jonathan Parry, 1-44. Cambridge: Cambridge University Press.

Çirozlar, Hasan. 2011. Interview. Çirozlar Süt Mamülleri, Büyük Evren Köyü, Enez, Turkey, 26 May.

Cloake, Felicity. 2016. "The Time Is Ripe for British Cheese." Guardian, 30 July.

Cory, William Johnson. [1858] 1905. Ionica. London: George Allen.

Dawson, Chris. 2010. Interview. Waitrose, Bracknell, Berkshire, United Kingdom, 4 February.

Desilvey, Caitlin. 2017. Curated Decay: Heritage beyond Saving. Minneapolis: University of Minnesota Press.

Dickens, Charles. [1859] 2003. A Tale of Two Cities: Penguin Classics.

Fabre, Daniel. 2007. "Patrimoine et Culture Paysanne." Les invités d'Agromip 9 (automne 2007): 20-24. Accessed 3 January 2013.

Gade, Daniel W. 2004. "Tradition, Territory, and Terroir in French Viniculture: Cassis, France, and Appellation Contrôlée." Annals of the Association of American Geographers 94(4): $848-67$.

Gida, Çiftçiler. 2011. Interview. Kirklareli, Turkey, 28 May.

Hamarat, Huseyin, and Azize Hamarat. 2011. Interview. Demirköy Süt Ürünlerı, Demirköy, Kirklareil, 27 May.

Hodgson, Randolph. 2007. "The Creation of a New Traditional Cheese." SOAS Food Forum, Food Studies Centre, SOAS, University of London, 26 October.

Hyatt, Christine, Ricki Carroll, Allison Hooper, and Ari Weinzweig. 2008. "A.C.S. at 25 Years: Looking Back, Looking Forward." American Cheese Society 25th Anniversary Conference, Chicago, Illinois, 24 July.

Jenkins, Steven. 1996. Cheese Primer. New York: Workman.

Kap, Metin. 2011. Interview. Egneada, Turkey, 28 May.

Kardeş, Mahir. 2011. Interview. Kars, Turkey, 8 June.

Kass, Leon R. 1994. The Hungry Soul: Eating and the Perfecting of Our Nature. New York: Simon and Schuster.

Kindstedt, Paul. 2005. American Farmstead Cheese: The Complete Guide to Making and Selling Artisan Cheeses. White River Junction, VT: Chelsea Green.

Klein, Jakob A. 2018. "Heritagizing Local Cheese in China: Opportunities, Challenges, and Inequalities." Food and Foodways 26(1): 63-83.

Koçulu, Ilhan. Interview. Boğatepe, Kars, Turkey, 9 June.

Lassalle, Julien. 2009. Interview. Lourdios, France, 20 July.

Lévi-Strauss, Claude. 1966. "The Culinary Triangle." Partisan Review 33(4): 586-95.

Lichfield, John. 2005. "The Death of a Cheesy Tradition." The Independent, 1 August. www.independent.co.uk/news/world/ europe/the-death-of-a-cheesy-tradition-501006.html.

Lowenthal, David. 1985. The Past Is a Foreign Country. Cambridge: Cambridge University Press. 
MacDonald, Ken. 2013. "The Transnational Life of Cheese." In A Companion to Diaspora and Transnational Studies, edited by Quayson Ato and Daswani Girish, 293-315. Malden, MA: WileyBlackwell.

Marsh, Peter. 2009. "Sweet Smell of Success in Cheese League." Financial Times, 19 December.

McGee, Harold. 2004. McGee on Food and Cooking: An Encyclopedia of Kitchen Science, History and Culture. London: Hodder \& Stoughton.

Mons, Herve. 2008. Interview. Mons Fromager Affineur, SaintHaon-le-Châtel, France, 29 October.

Ocejo, Richard. 2017. Masters of Craft: Old Jobs in the New Urban Economy. Princeton, NJ: Princeton University Press.

Oikonomou, Andromachi. 2ol1. Interview. Senior Researcher, Hellenic Folklore Research Centre, Academy of Athens, 14 February.

Paxson, Heather. 2013. The Life of Cheese: Crafting Food and Value in America. Berkeley: University of California Press.

Petrini, Carlo. 2007. "Foreword." In The Atlas of American Artisan Cheese, edited by Jeffrey P. Roberts, ix-x. White River Junction, VT: Chelsea Green.

Rozin, Paul. 1999. "Food Is Fundamental, Fun, Frightening, and Far-Reaching." Social Research 66(1): 9-30.

Schneider, Joe. 2006. Interview. Collingthwaite Farm, Cuckney, Nottinghamshire, United Kingdom, November-December.

Slow Food. 2013. "What Cheese Will You Save." Accessed 17 September 2013. www.slowfood.com/international/slow-stories/ $192043 /$ what-cheese-will-you-save-/q $=638278$.

Steele, Norman, Veronica Steele, and Quinlan Steele. 2009. Interview. Milleens Cheese, Eyeries, Beara, County Cork, Ireland, 9 April.
UNESCO. 2003. Convention for the Safeguarding of the Intangible Cultural Heritage 2003. Paris: http://portal.unesco.org/en/ev.phpURL_ID=17716\&URL_DO=DO_TOPIC\&URL_SECTION= 201.html.

van de Voort, Jan Dirk. 2009. Interview. Remeker Jersey Boerenkaas, Lunteren, Netherlands, 17 April.

van Leeuwen, Trees. 2009. Interview. Kaasboerderij de Keizershof, Zoeterwoude, Netherlands, 15 April.

Werlin, Laura, Bill Hanson, Steve Jones, and Cathy Strange. 2008. "Is Selling Up Selling Out?" American Cheese Society 25th Anniversary Conference, Chicago, Illinois, 26 July.

West, Harry G. 2013. "Appellations and Indications of Origin, Terroir, and the Social Construction and Contestation of PlaceNamed Foods." In The Handbook of Food Research, edited by Anne Murcott, Warren Belasco and Peter Jackson, 209-28. London: Bloomsbury.

. 2014. "Bringing It All Back Home: Reconnecting the Country and the City through Heritage Food Tourism in the French Auvergne." In Food between the Country and the City: Ethnographies of a Changing Global Foodscape, edited by Nuno Domingos, José Manuel Sobral, and Harry G. West, 73-88. London: Bloomsbury. . 2016. "Artisanal Foods and the Cultural Economy: Perspectives on Craft, Heritage, Authenticity and Reconnection." In The Handbook of Food and Anthropology, edited by James L. Watson and Jakob A. Klein, 406-34. London: Bloomsbury. and Nuno Domingos. 2012. "Gourmandising Poverty Food: The Serpa Cheese Slow Food Presidium." Journal of Agrarian Change 12(1): 120-43. 